\title{
The Impact of Service Learning on Leadership Skills of Students who are Gifted and Talented in the Middle School
}

\author{
Patricia Anne Coon \\ West Virginia University
}

Follow this and additional works at: https://researchrepository.wvu.edu/etd

\section{Recommended Citation}

Coon, Patricia Anne, "The Impact of Service Learning on Leadership Skills of Students who are Gifted and Talented in the Middle School" (2013). Graduate Theses, Dissertations, and Problem Reports. 372.

https://researchrepository.wvu.edu/etd/372

This Dissertation is protected by copyright and/or related rights. It has been brought to you by the The Research Repository @ WVU with permission from the rights-holder(s). You are free to use this Dissertation in any way that is permitted by the copyright and related rights legislation that applies to your use. For other uses you must obtain permission from the rights-holder(s) directly, unless additional rights are indicated by a Creative Commons license in the record and/ or on the work itself. This Dissertation has been accepted for inclusion in WVU Graduate Theses, Dissertations, and Problem Reports collection by an authorized administrator of The Research Repository @ WVU.

For more information, please contact researchrepository@mail.wvu.edu. 
The Impact of Service Learning on Leadership Skills of Students who are Gifted and Talented in the Middle School

\title{
Patricia Anne Coon
}

Dissertation

Submitted to the College of Education and Human Services

at

\author{
West Virginia University \\ in partial fulfillment of the requirements for the degree of \\ Doctor of Education, Ed.D. \\ Educational Psychology \\ Department of Learning Sciences and Human Development
}

\author{
Jill Olthouse, Ph.D. \\ Joy Faini Saab, Ed.D. \\ Luise B. Savage, Ed.D. \\ Barbara Warash, Ed.D. \\ Richard T. Walls, Ph.D, Committee Chair \\ Department of Learning Sciences and Human Development
}

Morgantown, West Virginia

2013

Key Words: Gifted and Talented, Leadership Skills, Service Learning 


\author{
Abstract \\ The Impact of Service Learning on Leadership Skills \\ of Students who are Gifted and Talented in the Middle School
}

\title{
Patricia Anne Coon
}

This investigation relates to the impact of service learning on leadership skills of students who are gifted in the middle school while the students plan the project in-school and execute their goals out-of-school for their yearlong service learning project called Community ProblemSolving, or CmPS. Based on surveys, observations, and interviews from 25 students identified as gifted in the middle school, this study describes the student responses and observations from the researcher and teacher of the gifted. Findings show that most of the students in the study felt that their yearlong service learning project positively impacted their leadership skills. The data reveal some grade, age, and gender variances in the post survey because they spent more time sharing ideas and implementing their goals for their service learning project. Contributions this study makes to the existing literature in gifted education are to consider service learning as a part of gifted programming at the middle school level. 


\section{TABLE OF CONTENTS}

CHAPTER I. INTRODUCTION...............................................

CHAPTER II. LITERATURE REVIEW .......................................5

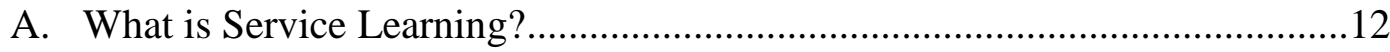

B. Service Learning and Leadership...................................... 17

C. Gifted Students and Service Learning................................21

D. Implications for Research........................................... 27

E. Research Question.................................................. 30

CHAPTER III. METHOD................................................... 31

A. Participants and Settings............................................. 31

B. Measurement..................................................... 32

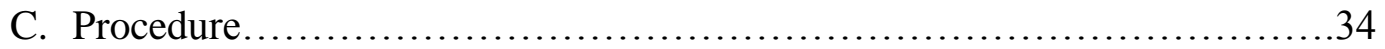

CHAPTER IV. RESULTS................................................... 38

A. Pre Survey In-School Totals.....................................40

B. Pre Survey Out-of-School Totals..................................41

C. Observation by Researcher.............................................43

D. Observation by Teacher of the Gifted...................................44

E. Post Survey In-School Totals ......................................47

F. Post Survey Out-of-School Totals....................................48

G. Interview Themes..............................................49

CHAPTER V. DISCUSSION ............................................ 51

REFERENCES...............................................................

APPENDIX A.............................................................64

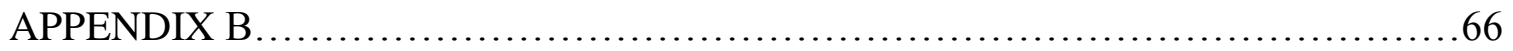

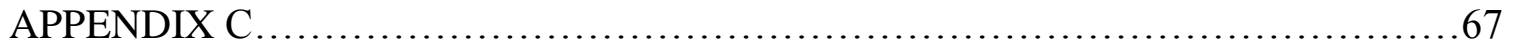




\section{Chapter 1}

\section{Introduction}

Service learning has been growing in popularity across the United States for many years, as exemplified in the research conducted by the National Student Service-Learning and

Community Service Survey in 1999. At the time of this study, which was the first national-level study of service learning in the United State's K-12 public schools, it was found that $64 \%$ of all public schools participated in community service activities, $83 \%$ of which were high schools. Most of the schools surveyed believed that an outcome of service learning consisted of the strengthened relationships between the students and the community, which was also one of the main reasons for the continuance of such practices.

Because the definition and delivery of service learning needs more criteria by which to describe it, service learning can take on different formats in the program in which it appears. In general, the National Commission on Service-Learning describes the characteristics of service learning to include links between academic content and standards. It includes the involvement of young people to meet and define real community problems that are reciprocal in nature in regard to benefitting both the community and the service provider. Service learning is relevant to any subject as long as it is connected to a real learning goal and works with all ages, even with young children (National Service-Learning Clearinghouse, 2012).

Gifted education began at the beginning of the twentieth century, when the advancements in education and psychology provided credence for the field. Early studies of giftedness from the 1920-30s grew from research on mental inheritance, subnormal children, and construction of instruments to measure intelligence. This led to the understanding that schools may not meet the needs of all children. Lewis Terman and Leta Hollingsworth were leaders in the movement to 
support gifted education, and also conducted some of the first widely publicized research studies on gifted children.

As the needs of the United States changed, gifted education began to evolve, especially in response to the Soviet Union's launch of Sputnik in the late 1950s. America wanted to foster leaders in our country to compete with other global powers, and to develop innovative and visionary contributors to our country and society. The federal government produced legislative effort in the early 1970s, which brought the needs of the gifted into focus. Defining giftedness also increased the programming options for the gifted that are still in place today, and assists students who are gifted and talented to reach each person's individual potential.

Near the end of the century, federal monies from the Jacob Javits Gifted and Talented Students Education Act funded the National Research Center on the Gifted and Talented, which provided grant monies for research and programming in gifted education. Two federal reports, $A$ Nation at Risk: The Imperative for Educational Reform (1983) and National Excellence: A Case for Developing America's Talent (1993), highlighted how opportunities to identify and serve gifted students nationally were being overlooked. A call was made for more research and programming in gifted education. The National Association for Gifted Children provided national standards for gifted education, to provide schools across the United States with criteria by which to evaluate gifted programs. Within those standards, leadership is a criterion (4.3), with evidence-based practices that accompany it (National Association for Gifted Children, 2012).

In 2004, A Nation Deceived: How Schools Hold Back America's Brightest Students reported on the advantages of acceleration for students who are gifted, and also indicated 
America's lack of ability to appropriately meet the needs of its most able students despite the overwhelming research that supported acceleration. Research supports students being moved ahead in school, because they tend to be more ambitious, and earn graduate degrees at higher rates than other students. We are in a new century, where unlimited possibilities should be a national emphasis for students who are gifted and talented, so they can become leaders in their fields and in our nation (National Association for Gifted Children, 2012).

However, since service learning fundamentally consists of involvement in learning about and working in the community to resolve problems, it can be a great tool to consider when working with middle school students who are identified gifted. This is because service learning can address the very unique needs and nature of gifted students who are of middle school age through real life connections to work and problems in society. It can be a motivating factor for students who are both gifted and in middle schools, and can have a positive impact on selfesteem and self-worth that can enhance their future schooling and career choices (Renzulli, 2005).

For instance, experts on curriculum for the gifted and talented stress the importance of a balance between the development of cognitive and social-emotional abilities. Researchers have demonstrated the connection between development and self-esteem and cooperative learning, especially in the middle years (Elmore \& Zenus, 1994). Therefore, any activities which involve the accelerated work and affective development, which are two components within service learning, should be a consideration when building a curriculum for middle school gifted students.

Community service is now a requirement in many high schools and colleges throughout the country. In the Campus Compact Annual Service Statistics of 2011, it was noted that among 
the 697 colleges campuses surveyed, 2,174,470 students participated in some form of service, and 47,454 service-learning courses were taught (Campus Compact, 2011).

Therefore, it is reasonable to consider that service learning may be beneficial for students who are gifted to engage in earlier than high school. By working in their communities through service learning, they would be more prepared to address global issues, such as social, political, economic, and environmental, from previous experiences volunteering and making a difference.

An intriguing factor related to service learning and gifted programs is the effect that service learning has on the students involved, and how service learning impacts the demonstration of their leadership skills. To date, there has been little research on how students in gifted programs in middle schools exhibit this phenomenon, so that is the direction this study will take.

The purpose of this study is to survey the general effects of service learning and, more specifically, the demonstration of leadership skills by middle school students in gifted programs. This study will examine the students who are identified as gifted at Westwood Middle School in Morgantown, WV, observing the rate of their demonstration of leadership skills when participating in service learning. It will consist of a Single-Case Design, which will involve a small sampling of middle school sixth through eighth grade students who are identified as gifted. 


\section{Chapter 2}

\section{Literature Review}

This literature review explores leadership skills and service learning in education, especially as it relates to gifted education. It is based upon research in the field that involves service learning and the demonstration of leadership skills. It focuses on studies that relate to the demonstration and observation of leadership skills in gifted education and service learning, as well as implications for future research.

Students with special needs, such as the gifted, can sometimes be isolated from their peers, both socially and physically, which can affect their confidence and engagement with peers and others. A study conducted by Robin M. Smith in 2009 was based upon several short case studies of particular children with special needs. The children were encouraged to use leadership skills and provide service. The results showed improved peer interactions, engagement, and self-confidence for the children participating.

There were five strategies and/or principles that emerged which supported service and leadership roles. They were quality of life, expansion of communication strategies, leadership, capitalization on strengths and interests, and exploration of problems other than special needs. There were areas that impacted the quality of the school experience. Most of the students in the study were of elementary age, yet the author believed that the findings from the cases could still be applied at any age and ability level in regard to how leadership and service can improve peer relations, self-confidence, and engagement in learning. She felt that all students "crave the meaningful and reciprocal relationships that leadership and service inspire” (Smith, 2009). 
The activities and examples used with the children related to leadership skills in the classroom, during free time in school, and after school. The study consisted of informal analysis, based upon a small sampling of students. The data indicate that there may be a positive correlation between students performing service to others and improving leadership skills (Smith, 2009).

The characteristics of gifted students in general include the potential for leadership. Therefore, leadership development for gifted students has long been a consideration in gifted programs. As education continues to be more global in nature, there is no doubt that leadership development should continue to be an integral aspect in gifted programs.

In regards to this assertion, a study which explored the relationship between thinking styles and scientific giftedness was conducted at two science high schools and the general high schools in Korea. The students participated in the Thinking Styles Inventory (Sternberg, 1990) and the Scientific Giftedness Inventory (Shim \& Kim, 2003). The results of the study demonstrated that students who were gifted had higher scores than non-gifted students in all areas, which included scientific accomplishment, leadership, creativity, morality, motivation, and cognitive experimentalism.

Interestingly, in a quantitative study investigating the thinking styles of Korean gifted students, it was noted that the gifted students had a preference for legislative, judicial, anarchic, global, external, and liberal styles of learning. They found that gifted students preferred complex problems that challenged them to use their own knowledge, and that they could act as leaders among their peers, express their own beliefs, and understood the opinion of others. When developing gifted education, it is important to consider such findings in regard to best practices 
that include the development of leadership, morality, and motivation so that students have opportunities for affective development in gifted education (Park, Park, \& Choe, 2005).

There have been many programs for gifted students to date that have included leadership development. One of them is the Schoolwide Enrichment Model (Renzulli, 2005) for elementary and high school students, which integrated a range of advanced learning experiences and thinking skills into all curricular areas.

Another such program focuses on developing leaders in environmental health. It is called the Environmental Health Sciences Research Center (EHSRC), and is based at the University of Iowa with its partner component, the Belin-Blank International Center for Gifted Education and Talent Development. It is a summer program, called the Environmental Health Sciences Institute for Rural Youth (EHSI) that has been in effect since 1997. Rising $10^{\text {th }}$ graders participate in an intensive program whereby they develop leadership qualities and learn information related to environmental health that they share with their own communities upon completion of the program (Tillett, 2005).

In addition, there is a talent search model at the Center for Talent Development (CTD) at Northwestern University which is designed to impact the local schools for the students who are gifted and talented. Developed over 20 years ago, the model focuses on increasing abilities from childhood through adolescence, which also include the areas of leadership and synergy of partnerships between the university and other leaders. Definitive steps are taken, such as testing elementary students in a talent search, a Saturday enrichment program and Leapfrog program for preschool and early elementary students, an Apogee program for grades 4-6, the Equinox program for high school students, and courses in a distance education program called Learning 
Links for grades 4-6. Some of the topics in the leadership program include "Order in the Classroom," "Youth and Society," and "Civic Leadership Institute," which all link to each other as the students progress from elementary to middle to high school years. Another thrust of the program is to include students who are under-represented groups within the gifted population, such as those whose home and/or school environments did not foster the development of intellectual abilities. Projects such as "Excite," "Quaker Oaks," and the "Jack Kent Cooke Foundation Young Scholars Program" identify students of color, inner city schools, and students with limited family resources to participate in leadership training and development. Studies conducted by CTD have produced evidence that students who have participated in programs that link high intellect with leadership are more motivated to take a more demanding course of study and attend more selective colleges (Olszewski-Kubilius, 2005).

Other countries, such as China, have also built a rationale for the inclusion of leadership development in training their gifted and talented students (Chan, 2000). Secondary students were taught the characteristics, skills and roles related to leadership while including creativity and futurism through a training program that would give opportunity for transfer of the skills through peer tutoring and counseling in their schools. The researchers concluded in their study that students favorably evaluated the value of the program, feeling that their leadership skills and creativity were both enhanced by the program (Chan, Cheung, Chan, Leung, \& Leung, 2000).

In 2002, the Kellogg Foundation initiated the Kellogg Leadership for Community for Change (KLCC). It is unparalleled by any previous program by the foundation in that it encouraged a shared leadership in a community setting. KLCC Session II, which began in the spring of 2005, was particularly focused on developing youth and adults as social agents of change. Although college level in nature and construct, the program has ramifications for public 
school usage as well. Impacts upon the students have included strengthening of cultural tradition and knowledge, interest in lifelong education, and a focus on community leadership through trust and meaningful relationships between students and their communities.

The Report on National Excellence (1993) noted a potential concern in regards to leadership, especially when it discussed how high-achieving students in America need to demonstrate leadership so that our country would "make economic strides." With regard to the "quiet crisis" in our country's politics, technology, and family income, especially in urban areas, a great need for reform exists, which includes the development of leadership development (Miserandino, 1994).

When exploring the responsibility of teachers of the gifted to differentiate instruction, the concept of addressing what and how a student learns, and his/her readiness and responsibility for learning, this can be an excellent match for the idea of leadership development. What better way to differentiate instruction than for the teacher to facilitate students as they take the initiative to select, plan, and execute a project within their own communities? All of these skills can foster leadership development, especially when the students are making choices, decisions, and evaluating their progress based upon a predetermined set of criteria (Tomlinson, 2004).

Some obstacles exist when teachers of the gifted attempt to implement best practices in gifted education, such as the inclusion of leadership development. In a study that traced teachers' use of gifted practices, it was discovered that teachers experienced obstacles which included feelings of isolation, resistant school structures, and scarcity of time in the school day to do what they wanted to do for all of their students (Cashion \& Sullenger, 2000). It was evident from the data that were collected over a two year period that some teachers had a fear of failure 
when strategies were too complex, and they were hesitant to try certain activities as a result. This could easily be the case when leadership and/or service learning activities are involved, because the development of either can extend beyond the classroom time when community involvement is a component.

Another concern in relation to providing opportunities for leadership development in gifted students is when they live in rural areas (Milligan, 2004). Because there may be smaller numbers of identified gifted students in the program, funding problems, and limited human resources available, special programs like Project Leadership Excellence Achievement and Performance (LEAP) and Team Lead might be more appropriate for the setting because it can provide for individualization, small groups, and projects that relate to leadership development despite the constraints of the rural environment. LEAP worked toward increased identification of giftedness in rural areas, curriculum development, and community and parental involvement, and increased participant scores on ACT and SAT testing. Team Lead, which was a voluntary leadership course, consisted of intensive academic content and a great deal of commitment and motivation from the students. Both programs were utilized at the high school level for students who are gifted and also have implications for consideration at the middle school level. Because the school the present study will be based on is considered rural, programs such as LEAP and Team Lead provide insight into positive effects that leadership development can make in the lives of students who are identified gifted and live in a rural community.

Other special programs that include leadership activities are some 2- and 4-year college programs in the United States (Booth, Sethna, Stanley, \& Colgate, 1999) and the Graduate Leadership Education Project on the Gifted/Talented (GLEP), which was a federally funded national leadership program in gifted education as a result of the Marland Report (Marland, 
1972) which noted a lack of leadership in the field of gifted education (Rudnitski, 1994). Seven universities designed the program to develop leaders in gifted education for the future, showing a necessity in the field of gifted education itself in the continual advocacy for programs of excellence. The purpose of the GLEP program was to produce leaders in the field of gifted education, since the interest and support for gifted education tends to wax and wane over the decades. More advocates are needed to sustain the field, and one way to accomplish that goal is through leadership in the field of gifted education. The strengthening of leadership for teachers of the gifted may also impact the leadership development for gifted students that they teach.

In an article on the implications of research related to gifted education, it is noted that there has been a paradigm shift as regards perspectives researchers have when considering their own assumptions about giftedness. The authors caution that in order to expand as a field, researchers need to understand each others' ideas about the concept of gifted education. The findings from any research impacts best practices, teacher preparation, and what the programs for the gifted include, such as learning styles and leadership potential. One of the reasons for conducting this study is to determine the impact of service learning on leadership potential, in order to possibly influence considerations for gifted programming options. The authors also stress the implications that research which is conducted to address a larger audience in education may also be of benefit to the overall support for gifted education (Friedman-Nimz, O’Brien, \& Frey, 2005). Conversely, one of the points I am hoping to support through my study is that service learning impacts leadership development for middle school students who are gifted. If this is the case, it will be explored how this could benefit other students as well in my discussion. 


\section{What is Service Learning?}

The National and Community Service Act of 1990 defined service learning as a method by which students learn and develop through curriculum integration and active participation in service experiences that are organized and address needs of their community. Newly acquired skills can be applied to real-life situations and can foster a sense of caring for others (National and Community Service Trust Act, 1990).

The history of the development of service learning dates back to 1903 , when the Cooperative Education Movement was founded at the University of Cincinnati. In 1905, William James and John Dewey created the intellectual foundations relative to service-learning. In 1915, some folk schools in Appalachia became two-and four-year colleges that connected work and service. From 1933 to 1942, the Civilian Conservation Corps (CCC) which was created by Franklin D. Roosevelt, consisted of youth who restored national parks, improved the economy, and supported themselves and their families.

In 1961, President John F. Kennedy set up the Peace Corps, which was accompanied by legislation to support it. Then, in 1961, President Lyndon B. Johnson developed VISTA, a National Teacher Corps, the Job Corps, which gave Americans full-time employment to assist low-income communities. In the 1970s, the Youth Conservation Corps had 38,000 youth involved in summer environmental programs.

The "Three Principles of Service-Learning” was published in 1979 in the Synergist. Through the 1980s, national efforts in service learning occurred at the grass roots level, which included service programs in higher education to develop future leaders through opportunities to serve communities. President George Bush created the Office of National Service in the White 
House Points of Light Foundation, which was developed to enhance volunteering. Since then, President Bill Clinton signed legislation which supported service learning opportunities, and the University of Colorado provided networking options through the internet.

The first International Conference on Service-Learning Research was held in 2001, the same year USA Freedom Corps was created to meet President George W. Bush's national call to service. In 2003, President Bush developed the President's Council on Service and Civic Participation and the President's Volunteer Service Award to recognize and thank those Americans who inspire others to volunteer service (Titlebaum, Williamson, Daprano, Baer, \& Brahlen, 2002). Many of the individuals who have advocated for the implementation of service learning in our society have been gifted leaders of our nation, and felt that through service learning, we could advance our contributions to society through the sharing of gifts and talents.

In a broad sense, the definition of service learning applies to a method of instruction which combines learning with community service. There are several levels of community service, ranging from surface to in-depth involvement. "Service" refers to unpaid assistance for individuals, organizations, communities, or the environment, and "learning" is the organized efforts that promote new skills and knowledge, especially related to having an in-depth understanding of social problems (Gray, Ondaatje, Fricker, Geshwind, Goldman, Kaganoff, Robyn, Sundt, Vogelgesand, Klien, Campbell, \& Rosenblat, 1999).

One model for service learning consists of a simple framework which includes Preparation, Action, Reflection, and Recognition. This helps new and veteran educators when developing educational opportunities for youth that result in a lasting and meaningful impact. Preparation includes experiences before actual service that engage the students in selecting, 
analyzing, and training for the project. Action is the service that must have academic integrity, be meaningful, and challenge the students as an outgrowth from the first level. Reflection allows for critical thinking through discussion, reading, and writing about the experiences. Recognition provides appreciation for the contributions of the students and finalizes the project of service (Duckenfield \& Hedin, 2000). These can be considerations for guiding principles that teachers use when adding service learning to their programming options.

Reflection is another important aspect of service learning, and it involves the development of skills such as critical thinking and brainstorming. It also encompasses the planning and execution of a service learning project, while making cognitive gains as reflection occurs throughout the on-going service learning project. Reflection includes having objectives, being involved, keeping journals as an individual and group, and discussing the project (ServiceLearning Tip Sheet, 2005). Students who reflect upon their service learning experiences can gain insights into how well they planned and executed their projects.

There have been many successes in presenting worth-while learning experiences for college students in their communities (Bonsall, Harris, \& Marczak, 2002). Leadership and civic responsibility have been the focus of several programs, such as the Excellence in Leadership Program at Ball State University, the Leadership for Change Program at Portland State University, and Leadership Development and Mentor Program at the University of Michigan. Activities such as service internships and mentorships are some of the leadership enrichment activities that are available. These elements can also be found in service learning opportunities at the high school and middle school level. 
In addition, there are academic benefits as well as civic responsibility that can be outgrowths of the goals of service learning. Even though research has been anecdotal in nature as to the relationship between service learning and academic achievement, the possibility of further research to discover any links seems worth exploring. Other benefits include opportunities for personal and social development as well as career exploration (Allen, 2003).

It is important to mention that when studying service learning, the amount of time invested in participation can provide insight into how behaviors are impacted. For example, there may be differences between students who participated in service learning throughout the school year as opposed to students who participated in service learning in one instance, or on a smaller scale.

There are national statistics that support the use of service learning in education, such as those represented by Growth to Greatness: The State of Service Learning Project. It was the first one of its kind to study service learning from a K-12 perspective. Some of the statistics include:

- $\quad 69 \%$ of K-12 public schools engage students in community service

- $\quad 30 \%$ of K-12 public schools involve students in service learning

- $\quad$ principals from low-income communities say that service learning positively affects academic achievement and school engagement

- 8 out of 10 principals say that service learning has a positive impact on academic achievement, teacher satisfaction, school climate, and the community's view of youth as resources

Even though the perception of service learning is positive, the study revealed that there is a lack of funding or infrastructure to support it (Kielsmeier, Scales, Roehlkepartain, \& Neal, 2004). 
The University of Florida has developed programs within the state that exemplify the benefits of service learning that include some of the salient findings from studies related to service to community. Participants felt the program was a worthwhile, useful, and powerful learning experience (Conrad \& Hedin, 1991). Such research demonstrates that students who have had the chance to participate in the complexities of social problems through service learning have more ability to comprehend such situations than students who have been in more traditional learning environments (Eyler \& Giles, 1999).

One example of the programs in Florida includes the Pine Jog Environmental Education Center in West Palm Beach, where more than a dozen schools are trained to investigate environmental problems, examine solutions, and develop plans for implementation. Another is the Suncoast Earth Force in the Tampa Bay area. Both Pine Jog and Suncoast (Florida Learn \& Serve, 1999) are affiliates of a national program called Earth Force and provide students with community service opportunities that are both educational and service-related. Some students have written curriculum on fish sustainability, enhanced their school's energy efficiency, and improved water quality of their city (Easton \& Monroe, 2001).

Learning in Deed, a national initiative from the W. K. Kellogg Foundation, was created in 1999 to provide for service learning opportunities across America in the hopes that service learning would become a vital part of every classroom in the United States. As an outcome of that initiative, Learning in Deed gathered information about perceptions related to service learning. This research became "Perceptions: Understanding and Responding to What People Think about Service-Learning." Some of the survey results produced the following outcomes from parents and teachers: 
- Parents like that service learning could better prepare children for life's challenges

- Parents and teachers support service learning that had educational value

- Parents especially like that service learning taught values and respect

- Parents and teachers from urban schools believe that service learning can foster personal development, in such areas as pride, self-esteem, and empathy

Some barriers for service learning to occur include the concerns that teachers have for how service learning can be incorporated into teaching and the media's lack of information about service learning (Perceptions, 2000). These barriers may also have impacted the willingness of teachers to incorporate service learning into gifted programming options.

Another creation of the Learning in Deed initiative is the National Service-Learning Partnership (NSLP), which is currently the only national membership organization that brings together stake-holders in the support of service learning in grades K-12. It is developed to raise awareness and improve the quality of service learning through free membership and access to information about developments and legislation in the field. In addition, there is a National Commission on Service-Learning, listed on the website for NSLP. Such initiatives may need to be considered when teachers are looking for support and guidance to alleviate the barriers to service learning in educational programs for students who are gifted and talented.

\section{Service Learning and Leadership}

The research connected to service learning and leadership development points out the benefits that young people gain from involvement in service learning. For example, one study discussed service learning and the development of leadership skills as having a possible effect on learned helplessness and it's empowerment for youth (Mueller, 2005). 
The potential effect of service learning and leadership for an individual can be powerful. One individual, a technology education student who participated in various service learning experiences, related his perceptions in regards to his experiences. He found service learning and the leadership development it provided to be a "teaching strategy that can enrich student learning, enhance teaching, and revitalize the community” (Moser, 2005).

Most of the research on service learning and leadership has been conducted at the college level. More emphasis could be directed towards grades K-12, since there seems to be a national interest in providing quality experiences in service-learning to younger students, as evidenced in the previous studies.

One study of note surveyed 230 academically talented adolescents, and analyzed the effects of a service learning program on civic attitudes and behaviors. Three surveys were administered, which measured civic responsibility, civic behavior, and leadership skills. It was found that there were significant differences between the group that participated in a service learning program and another group that participated in an academic program. Students who participated in the service learning program demonstrated enhanced civic responsibility, especially in their awareness of civic issues and connection to commitment to community. There was not much difference in regard to civic behaviors or leadership skills as a result of the service learning program, according to this study. The researchers did feel that a more long-term study to examine what kinds of service learning the students chose to be involved in was needed (Lee, Olszewski-Kubilius, Donahue, \& Weimholt, 2007).

Another study by the same research team examined how students evaluated their service learning experiences with the Civic Leadership Institute (CLI) program. The CLI program 
combined service learning with civic engagement and used surveys from the program evaluations and narrative comments from the 230 gifted high school students who participated. Results were that the students believed that the coursework and hands-on experiences increased their motivation to be involved in social issues within the community, and they gained a new respect and acceptance of diversity (Lee, Olszewski-Kubilius, Donahue, \& Weimholt, 2008).

There are several programs and competitions that are available in the schools that focus on leadership and service learning. One such program is a place-based program in Hawaii, located in a rural high school for at-risk youth. The program is specifically designed to address low achievement and students with high drop-out rates.

The community was very involved in the program, contributing to the development of the program, supervising the students' service learning projects, and other involvements. There were challenges that accompanied the program, which included the lack of school leadership, teacher burnout, and interpersonal conflicts. An interesting factor of this study was how the community members impacted the lives of the students and why the community members were such important stake-holders in the program. The present study will also be conducted in a rural community, and some of the students who are identified gifted have the potential to be identified as underachievers, and already display at-risk tendencies to drop out from school. In the past, I have personally seen students who were not connected with school and learning find a connection with education when they stepped outside of the school environment and made a difference in their own community through participation in service learning programs.

Another program that is designated for high school students is the Duke University Talent Identification Program (TIP) Leadership Institute. It is a two-week summer experience 
and includes academic study with service learning. Ultimately, it helps students to realize and accept their individual abilities for leadership potential.

This program combines leadership skills and guided service learning opportunities, where students learn to identify important needs in their community. They work to address the identified needs, which is part of the authentic learning experience that promotes personal development. It also fulfills curricular objectives that connect to school and community.

In order for service learning to be most effective, it should be incorporated into a framework of leadership theory. The TIP director developed four areas that can be used in any leadership curriculum: theory and practice, real and imagined worlds, self-reflection, and leadership in action.

The Duke TIP Leadership Institute addresses both the cognitive and affective characteristics that relate to students who are gifted. The program states they provide the students with the following skills through this model:

- valuable, transferable skills through exposure to a variety of leadership theories

- $\quad$ analysis of different styles of leadership and interaction with real-life leaders

- $\quad$ engagement in self-reflection to define personal leadership preferences

- $\quad$ transform ideas, knowledge, and skills into original service learning experiences

Time constraints may impede the ability to provide service learning opportunities that develop leadership, yet it is well worth such consideration (Pleasants, Stephens, Selph, \& Pfeiffer, 2004). 


\section{Gifted Students and Service Learning}

Currently, students who are identified gifted participate in service learning through the community service requirement in many high schools throughout the United States. Some students who are gifted and in the middle schools participate in service learning through various levels of involvement, but it is not a requirement of either the school system or the gifted programs that are offered.

The research related to both service learning and its impact upon students who are gifted and in middle school is limited. One case study design consisted of gifted adolescents who participated in community action service learning projects. The perspectives of the students involved pointed out the appropriateness of service learning as being suitable to the concept of differentiated curriculum, as well as noting the benefits related to personal and social development, commitment, and empowerment (Terry, 2000). Despite the inability of most schools to provide experiences beyond the classroom in service learning, there being no clear conceptual framework for service learning and the fact that most research to date varied greatly in approach from study to study, the obvious potential for service learning opportunities to enhance character traits for students who are gifted remains promising.

A typography developed for grades K-12, based upon the degree of involvement of the students in relation to service, learning, and the community (Terry \& Bohnenberger, 1999), can be a helpful tool in regards to research initiatives. It includes community service through performing tasks that involve awareness, such as working with a nursing home. The next level involves awareness, exploration, and engagement, and can involve internships with a high degree of learning on the part of the student. The highest level is community action, whereby the 
student takes all of the previously mentioned skills from the previous levels to make a positive impact upon the community, seeing how he/she can make a difference in real world situations. Usage of such degrees in service learning for research purposes could deepen understanding of how service learning impacts students who are gifted within their communities.

An article about the trends in secondary schools for the education of gifted students addressed the benefits of service learning for this population. The author discussed how service learning can benefit not only students who are identified gifted but also bright and highly motivated students, especially in regards to self-esteem and self-efficacy (Terry, 2000).

Experiential learning, which includes service learning and cooperative education learning experiences, was the focus of a college study of students who are gifted. The authors discovered that the emergent themes from interviews with students were the benefits from the recognition of taking responsibility for learning, the unique challenges made possible by experiential learning, and learning from similarly engaged and maturing peers (Keen \& Howard, 2002). It would be interesting to replicate such a study in elementary, middle, and high school programs for students who are gifted to determine what themes would be evident at those levels.

The concept of mentorships should not be forgotten. As a direct result of working in the community through service learning, there is often a connection between the young people involved in service learning and their adult mentors. Since it is not always realistic to provide every child with a mentor there can be the option of an adult mentor who works with groups of students instead of individuals, and the students can still be nurtured through these efforts. One such program matched gifted under-achievers along with the academically and artistically talented students in mentorships through real-world experiences. A unique example of this 
format is Project Synergy, whereby students who were potentially gifted, economically disadvantaged, and young urban children in the middle schools were matched with potentially gifted kindergartners, which created a close bond between the two. Community-based mentorships have a reciprocal relationship as well, often providing both parties with real-life experiences that benefit local communities. Futuristically speaking, telementoring is a distance component of mentorships, but it can still facilitate personal development and even community service through the mentor's guidance through the internet (Schatz, 1999/2000).

Service learning activities provide excellent opportunities for leadership development, which are taught primarily by doing and serving the greater good, and align closely with the strong sense of altruism manifested by many students who are gifted (Clark, 2002). The National Council for Social Studies (1994) suggested that service learning can be an option for meeting standards within the social studies context as well.

According to Karnes and Bean (1996), extracurricular activities provide real-life options for students to practice leadership skills. Also, participation in community activities may assist in the transfer of leadership skills into adulthood.

When exploring options to meet the needs of gifted middle school students, some middle schools have chosen to use the National Research Center on Gifted and Talented Schoolwide Enrichment Model (SEM). Within that model, it has been found that using the Total Talent Portfolio (TTP), which includes information about each student's abilities, interests, and learning style preferences, is beneficial. Students are encouraged to set internal criteria to develop methods to deliver a product or service for a real-world audience. Through this, students gain autonomy and ownership of a project. Their social and emotional needs for self-concept and 
positive feelings about themselves are promoted by the level of involvement and cooperative learning experiences that are a part of the program (Renzulli \& Richards, 2000).

Since middle school students, including those who are gifted, struggle with significant issues in early adolescence related to the physical, psychological, and social changes, they often have been characterized as needing to explore a variety of interests, connect learning to practical life and work, release energy through activities and have fatigue due to the rapid growth they are experiencing, develop personal identity from peer affirmation, separate themselves from parents, and rely on friends to provide comfort, understanding, and approval (American School Counselor Association, 2012). As a result, middle school counselors find themselves using a variety of methods that meet such developmentally unique needs of this population of students. One of these methods is service learning because it gives middle school students opportunities to apply what they have learned in the classroom to service that can benefit their community. Critical thinking skills and reflection upon what they have participated in also assists them in academic, career, and personal/social development (Stott \& Jackson, 2005).

The examination of standards-based instructional practices by service learning at the implementation level revealed significant differences in how standards-based practices were used. The middle school teachers who participated in service learning strategies on a regular basis also reported using the standards-based practices for literacy, numeracy, and cross-content area practices. That find also supported the position argued by Waterman (1997) and Bhaerman, Cordell, and Gomez (1998), being that service learning is aligned and complementary with reform-recommended instructional practices for meaningful teaching and learning. The middle school teachers in the study provided their students with many opportunities to partake in and increase their higher-order thinking skills through activities that included small-group 
discussions, group projects, written reports, mathematical reasoning, and problem-solving, as well as community service involvement. That finding also supports Schollenberger's (1985) position that service learning has the potential to provide more opportunities for students to engage in higher order thinking. Certainly, these are many of the activities that are considered best practices for students who are gifted and in middle schools as well. The article also pointed out that most middle schools do not provide opportunities for service learning (Seitsinger, 2005). This is one of the reasons for my study, as most middle school gifted programs in the county I will conduct my study do not incorporate service learning as an option. Many of the teachers are aware of it, but only one teacher uses service learning with her students.

When creating service learning programs for students, it is important to find community members who are truly committed and interested in the student participants and to foster a connection to real-life applications of school learning to community engagement. Finding and sustaining community involvement in service learning involves school and community collaboration as well as a commitment to student development which is dependent upon a common set of values and flexibility. In their study, Yamauchi and Purcell had 15 organizations that participated in the Hawaiian Studies Program (HSP), and the community members contributed time, talent, and treasure to sustain the place-based high school program for at-risk youth. Because some gifted youth may develop at-risk tendencies and may drop out from such frustrations, service learning could be a positive intervention for consideration (Yamauchi \& Purcell, 2009). As mentioned earlier, I have seen this very phenomenon occur with my students who were identified gifted in the middle school when they participated in service learning.

A best-practice model has been developed in service learning for youth who are gifted. It infuses the Creative Problem-Solving process, the cognitive apprenticeship model, cooperative 
learning, reflection, and celebration (Terry \& Bohnenberger, 2003). It is one of many possible service learning vehicles that could be chosen to utilize as a method of instruction with a program for the gifted population. It is especially important to consider including a service learning component at the middle school level for students who are gifted, due in part as preparation for the national emphasis at the high school level for community involvement and to meet the unparalleled need for leadership development in students who are gifted at the middle school level while they are still developing individual goals and direction for the future.

Many of the examples provided are very similar to the Community Problem-Solving Program model, or the CmPS, which is the program that the students at Westwood Middle School currently use, and the focus of this study. It is a school-based program, involving planning at the school level, involvement in the community, and submission of the completed project for competition on the state and international levels (Pleasants, et al., 2004).

When students are participating in service learning that involves competition, another important consideration is the level of involvement and commitment from the parents of the students. Service learning competitions can impart such skills as leadership and problemsolving, and provide prizes for excellence in execution and completion of a service learning project. Because students are involved in local, state, national, and international competitions, fun in learning is a part of that process. However, parents also need to understand and acknowledge the commitment that is required on their part in both the service learning project and the various levels of competition. For example, many school service learning projects involve transporting students to the service learning site several times throughout the year. Competitions can be local, state, and even national and international. These include commitment of time, gas, and sometimes hotel and food on the part of students and parents. 
Competitions, such as Community Problem-Solving (CmPS) and others, are proven to motivate, enhance self-concept, address issues of subjectivity through real-world solutions, and provide opportunities for role modeling and adult supervision and support to occur.

Competitions are by no means limited to students who are gifted and talented, and it has been found that all students should be allowed consideration for participation in competitive academics (Ozturk \& Debelak, 2008).

There are benefits and drawbacks when a parent has a child involved in service learning and competition, and a parent needs to be aware of the level of commitment expected by both the student and parent when they assist and support this process. Although the rationale for continuance of service learning as a school project and competition includes the leadership and academic skills, such endeavors go well beyond the normal school hours (Karnes \& Riley, 2005). This is one of the reasons teachers are reluctant to participate in service learning, and that is one of the reasons for this study. It is hoped to demonstrate that the impact of service learning on the leadership skills of students who are identified in the middle school is worth the time and effort of the teacher, students, and parents.

\section{Implications for Research}

Presently, there has not been much research on the effects of service learning on students who are gifted at the middle school level, especially in regard to its affect upon leadership development. Most of the research on service learning to date had been conducted at the college level and some at the secondary level. Currently, there are middle schools in West Virginia who participate in various service learning experiences, but only in one school in the county will this study be conducted. 
It will be interesting to explore the impact of the effects of service learning on leadership development as it relates to middle school students who are identified as gifted, in order to determine what these stakeholders feel they have or have not gained from the experience. It may also be a consideration to understand what the teachers of the gifted, parents of gifted, and the community involved believe service learning has or has not contributed to the development of leadership in the students who have completed a service learning project.

Since the No Child Left Behind Act (NCLB, 2001) legislation emphasizes math and science scores to increase, it is understandable that a concentration on the development of problem-solving and leadership skills through service learning experiences would be beneficial. The idea can be proposed that the sooner students are exposed to such opportunities, the better the students may make the connection to real-world experiences and the impact of being independent learners. With the reauthorization of the Individuals with Disabilities Education Act (IDEA, 2004), and having to meet standards such as the National Council for Accreditation of Teacher Education (NCATE), it may behoove those involved in the field of education to consider service learning as an important component in any school system.

In addition, in a time when the school systems in the nation are calling for reform and revision, research from the field of gifted education may be of interest when looking for strategies that have positive results in regard to student engagement and performance that impact all curricular areas. Leadership development and service learning are two possible areas of research, not just for students who are gifted, but students of all abilities. The use of gifted pedagogy to infuse motivation and independence of each individual's learning may have a vital impact for students of all learning abilities to reach their truest potential (Renzulli, 2005). 
Service learning has been considered a positive reform option in education for many years, through the incorporation of community service experiences into the work that students participate in at the school level. Since the 1970s, teachers have become more interested service learning. In the 1990s, many initiatives became available which assisted in the growth of service learning (Skinner \& Chapman, 1999).

The study may garner information about how service learning and leadership skills are developed by the students who are gifted in the middle school, and also whether leadership development is increased when participating in a service learning experience. Implications from these data may assist in creating service learning experiences that are more beneficial for the parties involved, and have ramifications for educators as to the constructs of service learning in general and how it is best incorporated into programs for middle school students who are gifted so they will be more prepared for such experiences in high school. 


\section{Research Question}

What is the impact of service learning on leadership skills of students who are gifted and talented in the middle school?

\section{Definitions}

$\underline{\text { Gifted Programs }}$ - Any program in the state of West Virginia that meets the minimum requirements for service students who are gifted identified.

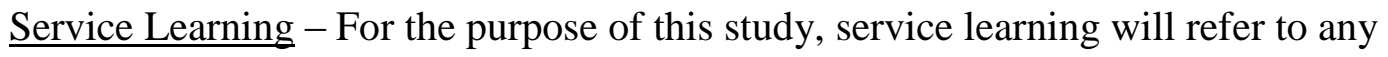
involvement in learning about and working in the community to resolve problems.

Leadership Skills - For the purposes of this study, leadership skills will refer to the leadership skills from the Scale for Rating the Behavioral Characteristics of Superior Students (Renzulli, Smith, White, Callahan, Hartman, \& Westberg, 2002), which contributes to each individual's ability to design, implement, and sustain a service learning project, and to use problem solving to identify and rectify the problems in the service learning project as an individual and/or group. The leadership skills for the survey will be modified from the Leadership section from the National Community Service Study that was developed by Brandeis University in 1995, and was part of a national study of schools and service learning. 


\section{Chapter 3}

\section{Method}

\section{Participants and Settings}

The participants were selected based on convenience, and consisted of sixth through eighth students who are identified gifted at Westwood Middle School, in Monongalia County schools. There are approximately thirty-five students who are identified gifted at this middle school, and there are boys and girls who range from the age of eleven through fourteen. All have been identified as gifted, which means that they have qualified through intellectual and academic achievement tests to participate in the gifted program, and each student has an Individual Education Plan (IEP) that is developed to meet individual needs that are serviced outside of the realm of the regular classroom. The students were surveyed as to their perceptions related to the impact of service learning, called Community Problem-Solving or CmPS on their leadership skills.

There was also more intense observation of a smaller subgroup within this population, consisting of sixth through eighth grade students who are identified gifted. These students were selected by a table of random numbers. These students were observed at Westwood Middle School while they were planning and executing their project and at the location of their project. The location was determined to be on the outside campus of their school when they selected the topic of building a greenhouse at the beginning of the school year.

The students participated in service learning through CmPS, both in school and out of school. The students selected the community problem to address, identified goals and objectives, and devised an implementation plan to carry out during the school year. They also developed 
criteria by which to evaluate their project. CmPS, a yearlong service learning project, is believed to foster leadership skills, and these skills can be observed by both their teacher and the researcher, the students own reactions to the pre and post survey, and individual interviews.

\section{Measurement}

The researcher examined the impact of service learning (independent variable) on the leadership skills (dependent variable) of the sixth through eighth grade students who are gifted and talented at Westwood Middle School. This was accomplished through a Single-Case experimental study, collecting both quantitative and qualitative data on the phenomenon through observation of the frequency of leadership skills in CmPS. It included a survey, observation, and interview. This format of a mixed methods study was selected because it had the flexibility to assist in evaluating the effect of service learning on the leadership skills due to its sensitivity to the small group of individuals that were observed. Target skills associated with leadership were operationalized, and both the teacher of the gifted and researcher observed the students in CmPS separately, keeping track of the frequency of the leadership behaviors. The students completed a pre and post survey, and interviews were conducted. These measures assisted in determining if leadership skills were occurring in the CmPS setting, and if there was any variance due to the grade levels, age, and genders of the students, according to the data gathered. Because there was direct observation involved, its strengths were that the observation occurred in real time and captured the event context. Its weaknesses were that it was time consuming, some facts may have been missed, and the mere presence of the researcher may have caused change in the natural reactions of the students. The teacher of the gifted and the researcher completed the observation chart of the leadership skills to compare results and to establish inter-rater reliability. The strengths of the student pre and post survey were the same as those of the direct observation, 
and provided insight from the data gathered from the target participants and comparisons of the results. Weaknesses were similar to the direct observation, including bias due to investigator actions, intended or unintended. The interview strengths included targeting the study topic and providing perceived causal inferences. The weaknesses included the possibilities of bias due to poor questions, response bias, incomplete recollection, and demand characteristics, where the student may express what he or she believes the interviewer wants to hear. Leadership skills were selected and were some of the same skills targeted across the surveys, observations, and interviews. These leadership skills may not be the only ones that could be have been occurring and that were shared with those reading the study results. It is hoped that the study demonstrated that service learning reliably produced a particular change in the students' behavior, so it would be interesting to learn if it occurred in the CmPS setting. Experimental control was important in this study in order to establish if there was a consistent effect on the dependent variable by systematically manipulating the independent variable.

In order to assure the reliability and validity of the measures, the survey, observation chart, and interview questions were focused around the same items that will measure the impact of service learning on leadership skills. The Leadership section from the National Community Service Study that was developed by Brandeis University in 1995, and was part of a national study of schools, and service learning was selected for this purpose. Over 1,500 students in 20 communities around the country participated in the survey, the results of which influenced programs that involved students and service learning. The content, criterion-related, and construct validity issues were assured through the selection of a portion of this survey that is related to leadership, and the items were adapted to be measured across the survey, observations, and interviews of the participants in the study. In that manner, there was more likelihood that the 
results of the study would measure if service learning is having an impact upon the students' leadership skills based upon the data collected from these three sources over the time of the study.

Internal consistency reliability for the survey was determined by calculating Cronbach's alpha for the results obtained. The concurrent validity of the survey was determined by the consistency of the results from the survey, observations, and interviews. The correlation between the survey results and results from the observations assessed concurrent validity. The relations between the interview results and the observations and survey results also assessed the concurrent validity of all three in a less formal manner. The less formal analysis consisted of determining if the students felt there was an impact from service learning on their leadership skills across the three measures, and the extent to which the results from the survey, observations, and interviews related to each other in regard to the items that were consistent among all three measures.

\section{Procedure}

The collection data began with the sixth grade through eighth students in the gifted program completing a pre survey of their perceptions regarding service learning, as it related to in-school and out-of-school experiences. Then, some randomly selected sixth through eighth grade students were observed as they participated in service learning through CmPS, and to observe the frequency of leadership skills demonstrated by the individual students in that setting. Finally, the sixth through eighth grade students were interviewed on a one-to-one basis, to gain more rich impressions of their service learning experiences. A post survey was also administered to see if there were any changes from the start to the end of the study. 
The participants experienced the presence of the researcher during the planning and execution of the project, and understood that they were being observed. The names of the students remained anonymous, with only ages, grade level, and gender included in the surveys, observations, and interviews. The study was not sensitive in nature, did not include at-risk or special populations, and the participants' identities were protected. IRB permission, consent, and assent were received prior to the study.

The study was completed during classes when CmPS was being planned or occurred. The teacher of the gifted and the researcher administered the pre survey, observed specific skills in leadership through the observation chart, and interviewed the students. They compared the frequency of occurrence of leadership skills in the CmPS setting. The students participated in a survey related to the leadership skills at the beginning of the study and at the end of the study. Observations were completed, and then the students were be interviewed. The data gathered from the survey, observations, and interviews were then analyzed to compare and contrast the results from the students as they participated in CmPS to see if any common themes occurred when comparing the three sources of data collection. Details of the study from start to finish were provided, so the procedures of this study could be easily replicated. Copies of the survey, observation chart, and interview questions were made available to whoever may wish to see them in the Appendices. The order of the procedures included administering the pre survey to the $6^{\text {th }}$ through $8^{\text {th }}$ grade students who are gifted, observing randomly selected $6^{\text {th }}$ through $8^{\text {th }}$ graders who are gifted from that group during CmPS for several weeks, interviewing the $6^{\text {th }}$ through $8^{\text {th }}$ grade students who are gifted in the last week of the study, and administering the post survey on the last day of the study to the initial group of $6^{\text {th }}$ through $8^{\text {th }}$ grade students. A checklist of the study plans was provided to the teacher of the gifted and the principal of the 
school, so they could verify that all of the procedures had been completed as stated, and they signed the checklist as a part of the verification process. This checklist was presented to both the teacher of the gifted and the principal, before the study began. A researcher's journal was kept throughout the study.

The study consisted of the comparison of the in-school versus out-of-school data, since the study occurred as CmPS was just beginning. Measures included within-subject Analysis of Variance (ANOVA), and measuring the frequency of the leadership skills as they occurred in the treatment, during CmPS service learning project. The study began when the treatment phase was starting, therefore the researcher and the teacher of the gifted observed service learning as CmPS was being introduced. Treatment fidelity was assured through the details of the measures of the study. This design assisted to answer the research question of whether or not there was an impact on leadership skills from CmPS service learning by the data collected when observing the students under those conditions (Kennedy, 2004). In addition, the students completed the survey at certain intervals, were observed, and were interviewed, in order to triangulate the data. This study determined if there was an impact of service learning on leadership skills since it was being studied both in-school and out-of-school to determine if the service learning CmPS project had an impact on the students' leadership skills.

The data collected represented the impact that the service learning had or did not have upon the leadership skills of the students who were the participants in the study during CmPS. The data were analyzed based upon the frequency of leadership characteristics that were observed as they related to the service learning treatment during CmPS. The leadership characteristics referred to the ability to design, implement, and sustain a service learning project, and to use problem-solving to identify and rectify the problems in the service learning project as 
an individual and/or a group. Some of the characteristics from the Leadership Characteristics section from the Scales for Rating the Behavioral Characteristics of Superior Students (Renzulli, et al., 2002) and the Brandies study were used to select leadership skills being observed directly for the survey, observation, and for open-ended questions during the interview. These sources were designed to obtain estimates of a student's characteristics in the area of leadership and were well suited to the research question, literature review, method, and design of this study. The results of the frequency of the behaviors were graphically displayed through figures that denoted the leadership skills during the times observed in CmPS. The mean frequency of the leadership skills in each observation environment was determined through analysis of the data. The trends found in the data determined if the research question produced the information to support that there is an impact from service learning on the leadership skills of the students in the study. It can also analyze the differences in variability and level changes between the service learning setting of CmPS and how the students from $6^{\text {th }}-8^{\text {th }}$ grade responded. From these results, it should be able to determine if service learning through CmPS had an impact upon the leadership skills of the students in the gifted program, in order to make the suggestion that service learning is a viable option for students who are identified as gifted and talented in the middle school. 


\section{Chapter 4}

\section{Results}

Westwood Middle School in Morgantown, West Virginia, was selected as the site for this study. It is the only middle school in Monongalia County that participates in CmPS, a yearlong service learning project for students who are identified gifted. Westwood Middle School is located in a rural part of the county, has approximately 500 middle school students in grades 6 through 8 , and more than half of the student population qualifies for free and reduced lunch. There is a wide variety of socio-economic backgrounds from impoverished to wealthy families.

The students have participated in CmPS for many years with the current teacher of the gifted. She has also worked with most of the current middle school students at the elementary level, but does not do CmPS until they are in middle school. Past projects that they have selected are "Paws and Think" and "Bartlett Buddies." "Paws and Think" was their 2011 service project related to the protection of exotic animals in Monongalia County. "Bartlett Buddies" was their 2012 service project connected to the Bartlett House for the homeless people in the area. They provided services all year, tutoring children in the shelter and arranging activities for the holidays. This year, the researcher followed them from the opening of the school year while they planned and executed some of the site activities for their CmPS service project.

Twenty-five students in the $6^{\text {th }}$ through $8^{\text {th }}$ grade who are identified gifted were administered the survey prior to planning their community service project. The survey consisted of ten questions (see Appendix A- Service Learning Survey) for in-school and ten questions for out-of-school when planning and implementing service learning. Both the researcher and the teacher of the gifted administered the same survey within a few days of each other to the same 
students in the $6^{\text {th }}, 7^{\text {th }}$, and $8^{\text {th }}$ grade who are identified gifted at Westwood Middle School. There was very little difference in the overall responses and totals for the students between the surveys given on either day by the researcher or the teacher of the gifted.

The overall responses toward service learning were favorable among the students in the pre survey. They are in the $6^{\text {th }}$ through $8^{\text {th }}$ grade, are between 11 and 14 years old, and are males and females. The SAS System was used to run an Analysis of Variance (ANOVA) procedure to determine if there were any significant differences within (a) grades, (b) ages, or (c) genders among the students. It was found that there were no significant differences in the responses among grades, ages, or genders. This could be due to the fact that the grades, genders, and ages were mixed among grades, or among the ages, or among the genders in the classes in which the surveys were conducted. Also, since the students had not begun their service learning project, they may not have much of an opinion as yet.

Of the averages of the responses given by the participants related to in-school in the pre survey, 18 percent of the students responded favorably to in-school planning of their service learning project by selecting "Strongly Agree" to the items related to service learning. Another 40 percent responded "Agree" to the items related to service learning. The other responses were 34 percent "Neither Agree nor Disagree," 6 percent "Disagree," and 2 percent "Strongly Disagree." Some of the most positive responses were to the items related to being aware of the needs in the community, believing students their age can make a difference, and continuing to do service learning projects in-school (see Figure 1). 


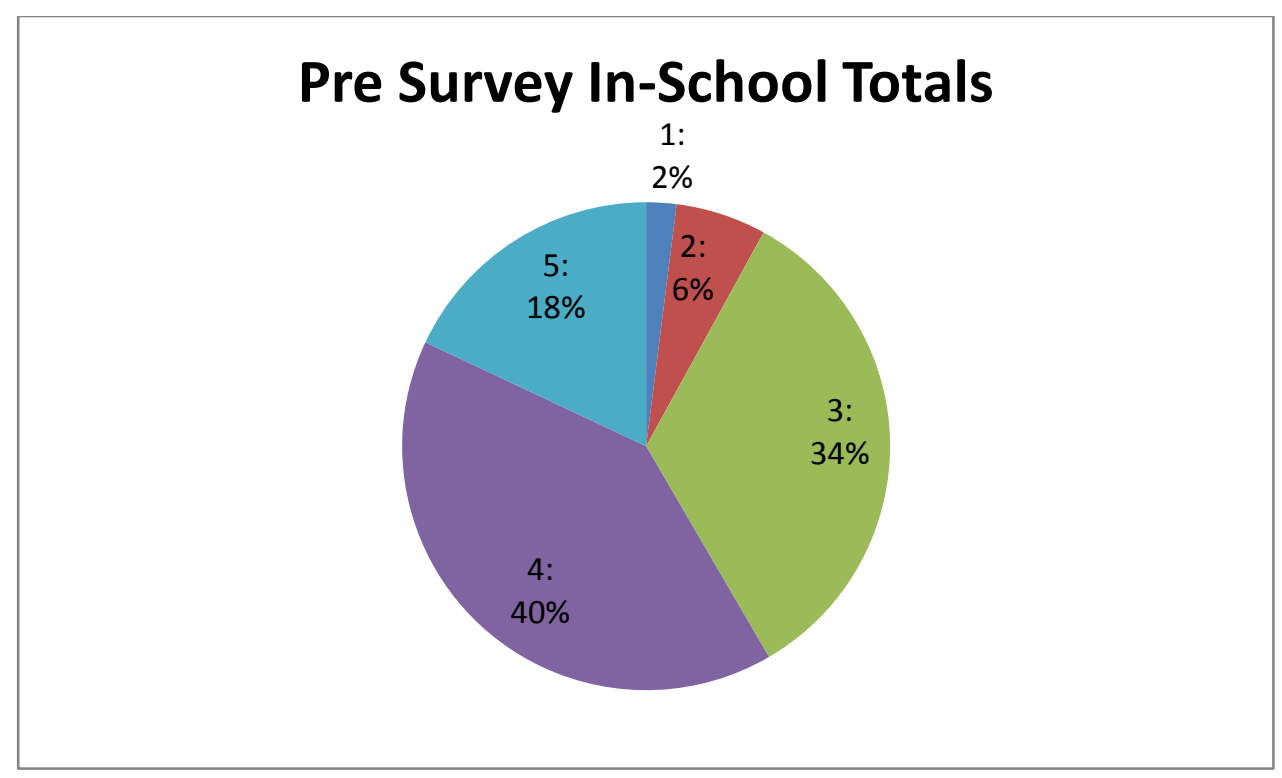

$5=$ Stongly Agree $4=$ Agree $3=$ Neither Agree nor Disagree $2=$ Disagree $1=$ Strongly Disagree

Figure 1. Pre Survey In-School Totals

The averages of the responses given by the participants related to out-of-school pre survey, 16 percent of the students responded favorably to in-school planning of their service learning project by selecting "Strongly Agree" to the items related to service learning. Another 38 percent responded "Agree" to the items related to service learning. The other responses were 39 percent "Neither Agree nor Disagree," 5 percent "Disagree," and 2 percent "Strongly

Disagree." Some of the most positive responses related to believing students their age can make a difference, knowing what skills are expected of a leader in service learning, and continuing to do service learning projects out-of-school (see Figure 2). 


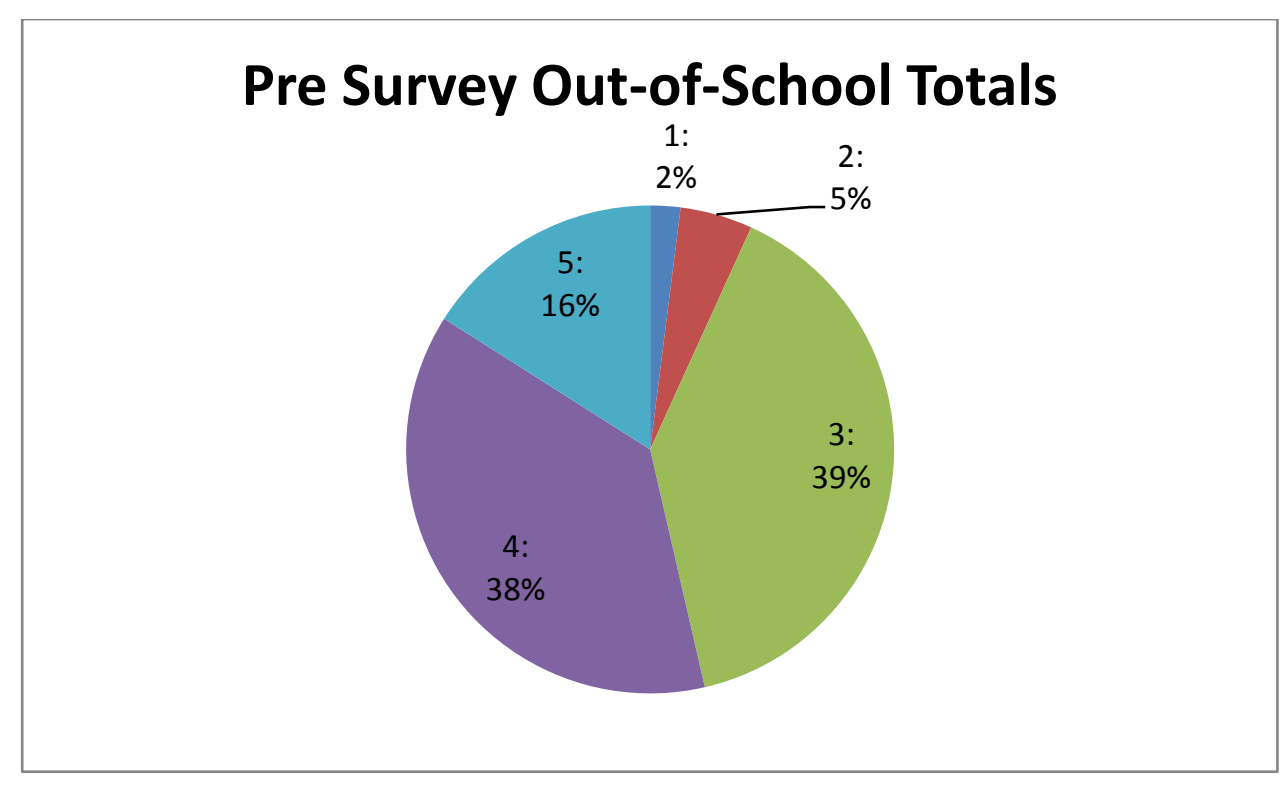

$5=$ Stongly Agree $4=$ Agree $3=$ Neither Agree nor Disagree $2=$ Disagree $1=$ Strongly Disagree

Figure 2. Pre Survey Out-of-School Totals

Here are some of the comments made by the students at the outset of their project:

"It is good to get not only gifted students, but all students involved in projects, this may increase awareness."

"I definitely $100 \%$ believe people 11 years of age and even younger can make a difference in our community."

"I like doing out-of-school projects more."

"We all have to work together to obtain our goal." 
There were five weeks of observation that followed the initial survey. Twelve students in grades 6 through 8 were randomly selected to be observed by both the researcher (see Figure 3) and the teacher of the gifted (see Figure 4) to establish inter-rater reliability. Week 1 consisted of discussing previous CmPS service projects, and brainstorming ideas for this year. Week 2, the students brought in research for each of the brainstormed ideas, such as building a greenhouse on their school campus, adopting an African child and the child's school, recycling, and Children's Hospital. Week 3, the students discussed their ideas and voted on their CmPS service project for the school year. They selected building a greenhouse on their school campus and composting from their school cafeteria. Week 4, the students went out onto their school campus with a compass to determine the best placement for the greenhouse, which they decided would be 8 feet by 12 feet in size. They also secured a donation from a local builder for their project. Week 5 , they visited West Virginia University's greenhouse for a tour and to ask questions regarding their project.

In Figure 3 and Figure 4, there was not much difference in the observations performed by the researcher (Figure 3) and the teacher of the gifted (Figure 4). Students who were in the 0-10 range on the bar graph were in the "Never" to "Rarely" range. Students who were in the 11-20 range on the bar graph were in the "Most of the Time" range. Students who were in the 21-30 range on the bar graph were in the "Always" range. Depending on the student, some demonstrated more leadership skills than others, while some did not exhibit leadership skills much or at all. For example, participants 21-6, 12-7, 1-8, and 2-8 exhibited leadership skills during service learning "most of the time." Participant 12-7 also exhibited strong tendencies for leadership over the entire observation period. There were students who were not formally observed by either the researcher or teacher of the gifted who displayed more leadership 
potential than some of those who were observed. Leadership skills included contributing ideas to their service learning project, discussing and applying ideas, working with others, and confidence in expression of their opinions and ideas in the group (see Appendix B-Service Learning Observation).

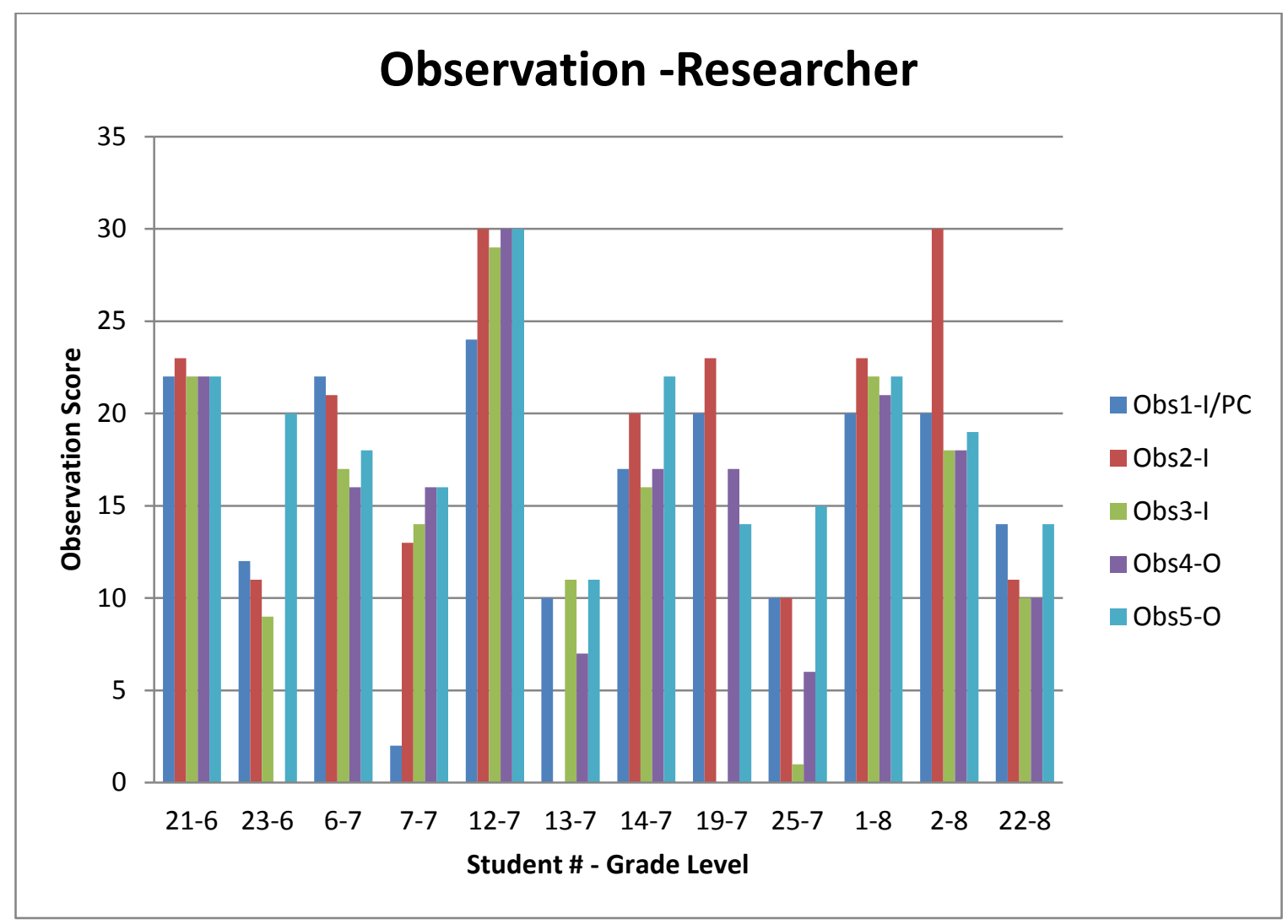

Figure 3. Observation by the Researcher 


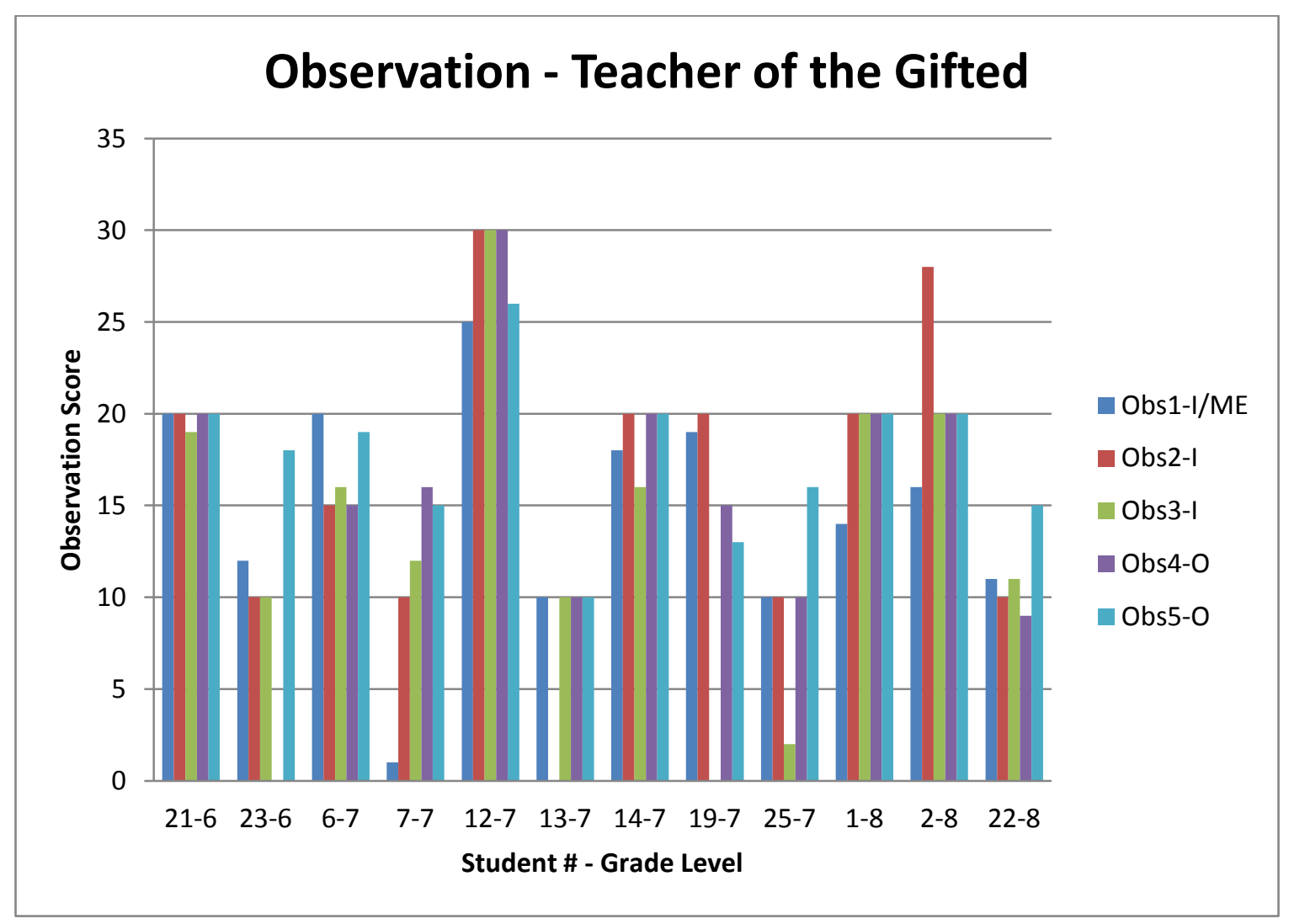

Figure 4. Observation by the Teacher of the Gifted

The overall responses toward service learning were favorable among the students in the post survey. They are in the $6^{\text {th }}$ through $8^{\text {th }}$ grade, are between 11 and 14 years old, and are males and females. The SAS System was used to run an Analysis of Variance (ANOVA) procedure to determine if there were any significant differences within (a) grades, (b) ages, or (c) genders among the students.

In regard to grade for In-School responses for the post survey, In-School item 1 had a trend toward significance, having an F value of 2.48 and probability of .10. In-School item 1 related to being "aware of needs in my community that I can do something about." For this item, 
students in grade 7 tended to select "Agree" and "Strongly Agree" more than those in grade 6 and 8.

In regard to Out-of-School responses, Out-of-School item 2 had significant difference, having an F value of 3.30 and a probability of .04. Out-of-School item 2 is related to believing "I personally can make a difference in my community." For this item, students in grades 6 and 7 selected "Agree" and "Strongly Agree" more than those in grade 8. Also, Out-of-School item 5 had significant difference, having an $\mathrm{F}$ value of 5.78 and a probability of .01. Out-of-School item 5 is related to knowing "what resources are available to help me with a service learning project." For this item, students in grades 6 and 7 selected "Agree" and "Strongly Agree" more than those in grade 8 .

In regard to age, there was not a significant difference for the In-School responses. For the Out-of-School responses, Out-of-School item 5 had significant difference, having an F value of 3.21 and a probability of .04 . Out-of-School item 5 is related to knowing "what resources are available to help me with a service learning project." For this item, students who were 11 and 12 years old selected "Agree" and "Strongly Agree" more than those who were 13 and 14 years old. Also, Out-of-School item 9 had a trend toward significance, with an F value of 2.50 and a probability of .08. Out-of-School item 9 is related to being "committed to service learning both now and later in life." For this item, students who were 11 and 12 years old selected "Agree" and "Strongly Agree" more than those who were 13 and 14 years old.

When it comes to gender for In-School responses, In-School item 4 had a significant difference, with an F value of 4.38 and a probability of .04. In-School item 4 is related to knowing "how to design and implement a service learning project." For this item, males selected 
"Agree" more than females, and females selected "Strongly Agree" more than males. Also, InSchool item10 had a trend toward significance, with an F value of 3.11 and a probability of .09. In-School item 10 is related to liking to "continue doing service learning projects in school." For this item, males selected "Agree" more than females, and females selected "Strongly Agree" more than males. In the observations, the researcher noticed the females tended to assume more leadership roles than the males in most cases, volunteering to take notes, lead the class in discussing and organizing their ideas, and making suggestions for the CmPS service project.

The changes from not having significance in the pre survey to having some significance in the post survey could be due to the fact that the students became involved in the selection, planning, and implementation of their service project after the pre survey. Their level of involvement may have increased among grades, age, and gender, which could explain the examples of significance described earlier.

Of the averages of the responses given by the participants related to in-school for the post survey, 21 percent of the students responded favorably to in-school planning of their service learning project by selecting "Strongly Agree" to the items related to service learning. Another 40 percent responded "Agree" to the items related to service learning. The other responses were 30 percent "Neither Agree nor Disagree," 7 percent "Disagree," and 2 percent "Strongly Disagree." Some of the most positive responses related to adults being supportive of their efforts, believing students their age can influence and impact the community, and continuing to do service learning projects in-school (see Figure 5). 


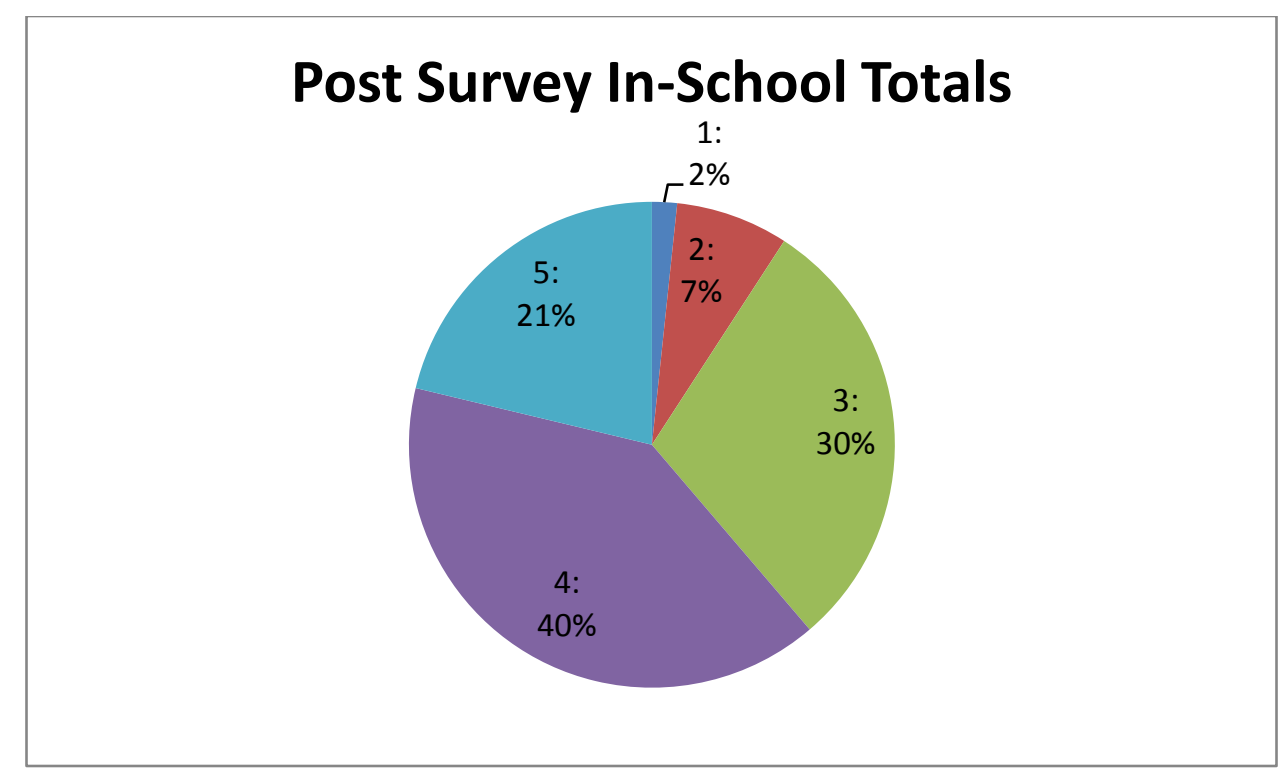

$5=$ Stongly Agree $4=$ Agree $3=$ Neither Agree nor Disagree $2=$ Disagree $1=$ Strongly Disagree

Figure 5. Post Survey In-School Totals

Of the averages of the responses given by the participants related to out-of-school post survey, 22 percent of the students responded favorably to in-school planning of their service learning project by selecting "Strongly Agree" to the items related to service learning. Another 33 percent responded "Agree" to the items related to service learning. The other responses were 38 percent "Neither Agree nor Disagree," 6 percent "Disagree," and 1 percent "Strongly Disagree." Some of the most positive responses related to adults being supportive of their efforts, believing students their age can influence and impact the community, and believing that they can personally make a difference in their community (see Figure 6). 


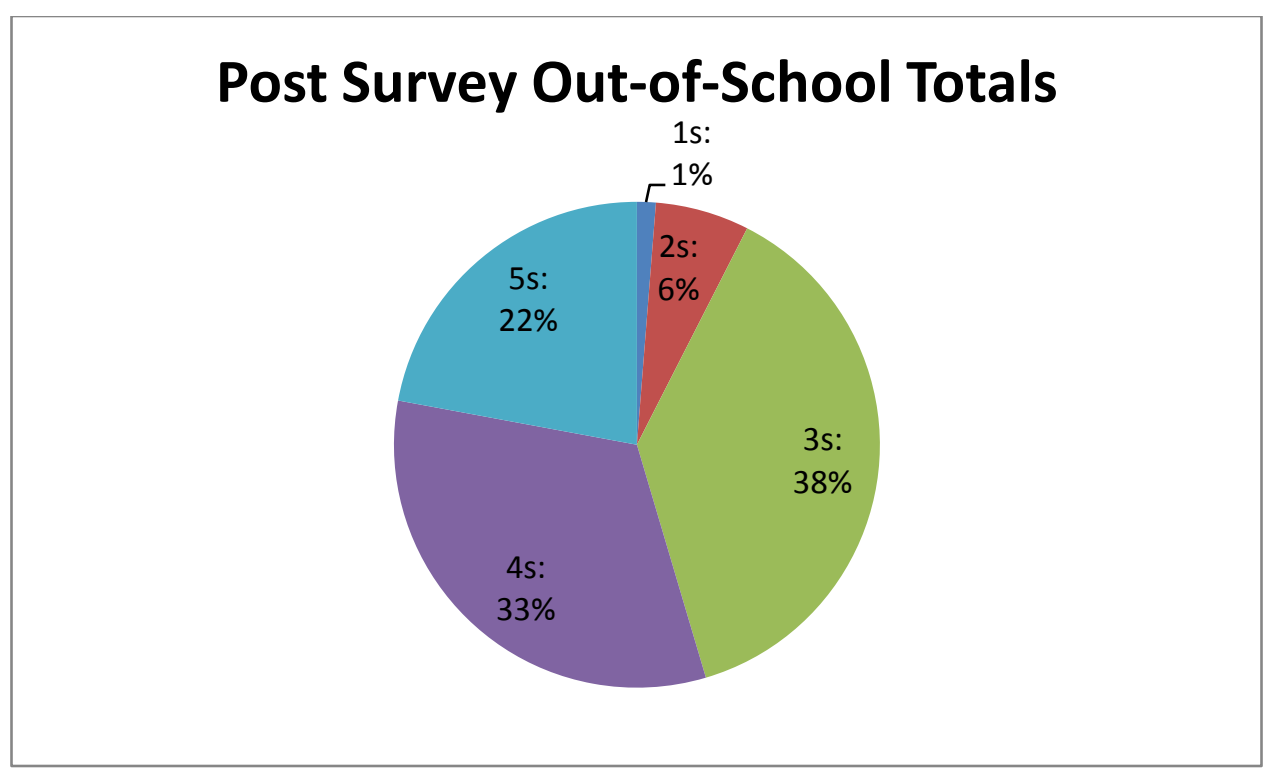

$5=$ Stongly Agree $4=$ Agree $3=$ Neither Agree nor Disagree $2=$ Disagree $1=$ Strongly Disagree

Figure 6. Post Survey Out of School Totals

Here are some of the comments made by the students after several weeks of working on their project:

"We will impact the community with school projects."

"I feel it is very important that students do community service in school so that later in life they will have the confidence to do it out of school."

"I believe the field trip definitely helped us with guidelines for the greenhouse."

"You learn even though it's outside of school."

When comparing the pre survey and post survey results, the students responded even more favorably in regard to service learning impacting their leadership skills. This was noted in the increase for both the In-School Responses and Out-of-School Responses on the post survey. 
Finally, all of the students who participated in the study were interviewed by the researcher after the post survey (see Appendix C-Interview Form). The responses were analyzed for themes.

Question number 1 was "How can you make a difference in your community through service learning?" Common themes among grade, age, and gender included "improving the lives of others," "raising money for them," and "making them happy."

Some particular responses of note were:

"If I see a situation, I know I can help."

"I can improve the lives of the community citizens."

Question number 2 was "Has service learning improved your leadership skills? If so, how?" Some common themes among grade, age, and gender overwhelmingly included "comfortable speaking with others and sharing ideas," "increased confidence," and "learning to solve problems on my own."

Some responses to note were:

"I've learned responsibility."

"Service learning helps me take charge, and crosses into other areas."

Question number 3 was "Is there another area of gifted programming or regular education that has provided you with the same leadership skills as service learning?" Most of the students responded "No," but some said that Future Problem-Solving, Sports, First Lego League, Student 
Council, and Boy Scouts provided some of the same leadership skills of team work, critical thinking, and problem-solving.

All of the participants were asked if they viewed CmPS service learning positively, neutrally, or negatively. All but two responded "positively," and the two who responded "neutrally" said they did so because they weren't far enough into the project to formulate an opinion as yet.

The researcher also interviewed a few parents, the teacher of the gifted, and the principal at Westwood Middle as to the impact of service learning on the leadership skills of students who are gifted and talented in the middle school. The parents weren't exactly sure what leadership skills were impacted, except one parent stated his daughter "always prepared and studied for the service project ahead of time because she valued it."

The teacher of the gifted felt that CmPS service learning could impact her students by "making a difference in their confidence, and helping them to support their thoughts with actions. Because it's all year long, they build confidence and willingness. The service learning starts slow and ends with everyone more involved."

The principal of Westwood Middle stated he felt service learning consisted of "team building, organization, respecting and using their talents for the good of society, and working with others. I don't think there's another area of gifted programming or regular education that provides the students with the same leadership skills as service learning. There is nothing else that has this scope of learning and leadership development." 


\section{Chapter 5}

\section{Discussion}

In summary, this study was designed to determine the impact of service learning on the leadership skills of students who are gifted and talented in the middle school. Research in the field suggests that students who are gifted benefit from the development of leadership skills. CmPS is a yearlong service learning project that can develop leadership potential over time. Some of the benefits include empowerment for youth, civic responsibility, and leadership skills. Service learning can also be suitable to the concept of differentiated curriculum, personal and social development, and commitment to task that is cultivated in gifted education.

There has not been much research on the effects of service learning on students who are gifted and talented at the middle school level, especially in regard to its effect on leadership development. This was the basis for the study.

The research question was "What is the impact of service learning on the leadership skills of students who are gifted and talented in the middle school?" The methods used were pre and post surveys, observations, and interviews.

The study was conducted at Westwood Middle School, the only school in Monongalia County that participates in a yearlong service learning project called Community ProblemSolving, or CmPS. The students started their service learning project at the beginning of the school year, and decided to build a greenhouse for the school campus and start composting from their school cafeteria. They secured a donation for an $8 \times 12$ foot greenhouse kit, and visited West Virginia University to learn about building and maintaining a greenhouse that would suit the needs of their school. They also created a site on "Donor's Choose," a non-profit website where 
they can receive donations for materials for the greenhouse, such as pots, soil, plants, and shelves. It is their idea to raise potted plants to sell, grow vegetables to donate to the needy, and possibly experiment with other ideas with the science department. The students felt that being on campus to do their service learning project this year would make it easier for more of the students to participate, since one area of difficulty for them in the past was getting to the out-ofschool site for their service project for CmPS.

The pre surveys were administered at the outset of the CmPS service project at the beginning of the school year. The results indicated the students seemed to favorably view the impact of service learning on their leadership skills, whether planning the project in-school or implementing their goals for the project out-of-school in their community. Then the researcher and the teacher of the gifted randomly selected twelve of the students to observe to gather further data as to the impact of service learning on the leadership skills of students who are gifted and talented. All of the students in the study were then interviewed by the researcher, one on one. At the end of the study, all of the students in the study were administered the post survey to determine if their opinions had stayed the same or changed in any manner as a result of selecting, planning, and implementing the goals and objectives of their service learning project.

There were some consistent themes among the surveys, observations, and interviews in the study. Many of the students felt that a yearlong service learning project through CmPS gave them confidence to share their ideas and opinions with a group of their peers, helped them become aware of and have an impact on their community needs, and to be able to make a difference through their problem solving skills. Because it is a yearlong service learning project, the interest and engagement of the students is sustained over a long period of time. In the interviews, the students overwhelming agreed that not many other areas of gifted education, 
regular education, or extracurricular activities could provide them with the same leadership skill development as their service learning project through CmPS. CmPS also involves research, team work, high order thinking skills, and technical writing skills. Extending this study across the entire school year would also have provided more insight into the "life cycle" of their service learning project. It would have been interesting to see if there was any change over time with the students who are gifted and talented as to how they viewed the impact on their leadership skills by the end of the school year.

For future studies regarding the impact of service learning on the leadership skills of students who are identified gifted and in the middle school, it would be worthwhile to consider a larger pool of participants at schools that are in rural, urban, and suburban areas. This study could also be replicated with students who are in the regular education and special education classrooms, to compare the results among the populations of varying abilities. Other leadership skills could be examined when developing the pre and post surveys, observations, and interviews, or added to the existing forms to provide more data and examine if there is a greater impact on leadership skills if more items relating to leadership skills were considered.

Another recommendation would be to eliminate the neutral ranking on the pre and post survey, leaving a 4-point scale of "Strongly Agree," “Agree," "Disagree," and "Strongly Disagree" as the choices. Then students would be more inclined to select either one of the more definitive answers and provide more data that could be analyzed as positive or negative regarding the impact of service learning on their leadership skills.

Also, such a study might be considered for a statewide, nationwide, or even an international study of students in the gifted program in the middle school who are participating in 
CmPS service projects. Since CmPS is a nationwide as well as a worldwide program, it would be meaningful to see if the results of this study are also noted in larger scale studies. There may also be some cultural differences if this study was conducted in an international context.

Elementary schools with students who are gifted can also participate in service learning projects through CmPS. If it is established that service learning through CmPS is a viable option for the development of leadership skills and potential for students who are gifted through more studies of this nature, then a study at the elementary level may be a consideration for the future.

In conclusion, based on the results from the data collected in the surveys, observations, and interviews, it appears that service learning positively impacts the leadership skills of middle school students who are gifted and talented. Leadership skill development is an important feature in gifted education, and a study of larger scale may produce more evidence to support it. In the future, consideration of service learning as a programming option in gifted education for middle school students would be an important strategy to develop leadership skills. It is an exciting possibility to enhance the skills of our future leaders! 


\section{References}

A nation at risk: the imperative for educational reform, April, 1983.

A nation deceived: how schools hold back america's brightest students, 2004 .

Allen, R. (2003). The democratic aims of service learning. Educational Leadership, $60,51-54$.

American School Counselor Association (2012). The ASCA national model: A Framework for school counseling programs. Alexandria, VA.

Bhaerman, R., Cordell, K., \& Gomez, B. (1998). The role of service-learning in educational reform. Needham Heights, MA: Simon and Schuster.

Bonsall, D.L., Harris, R.A., \& Marczak, J.N., (2002). The community as a classroom. New Directions for Services, 100, 85-95.

Booth, D., Sethna, B.N., Stanley, J.C., \& Colgate, S.O. (1999). Special opportunities for exceptionally able high school students: A description of eight residential early-collegeentrance programs. Journal of Secondary Gifted Education, 10, 195.

Campus Compact. (2011). Annual service statistics.

Cashion, M. \& Sullenger, K. (2000). Contact us next year: tracing teachers' use of gifted practices. Roeper Review, 23, 18-21.

Chan, D. W. (2000). Developing the creative leadership training program for gifted and talented students in Hong Kong. Roeper Review, 22, 94-96. 
Chan, D.W., Cheung, P.C., Chan, A.S.K., Leung, W.W., Leung, K. (2000). Evaluating the Chinese University Summer Gifted Program for junior secondary students in Hong Kong. Journal of Secondary Gifted Education, 11, 136-144.

Clark, B. (2002). Growing up gifted (6 $6^{\text {th }}$ ed.). Ohio: Merrill Prentice Hall.

Conrad, D. \& Hedin, D. (1991). School-based community service: What we know from research and theory. Phi-Delta Kappan, 72(10), 743-749.

Duckenfield, M. \& Hedin, D. (2000). An orientation to service learning. Service learning across the curriculum. Ed. Steven J. Madden. Lanham, Maryland: University Press of America, Inc.

Easton, J. \& Monroe, M.C. (2001). Enhancing natural resource programs with servicelearning. University of Florida Extension: Institute of Food and Agricultural Sciences, FOR 88.

Elmore, R.F. \& Zenus, V. (1994). Enhancing social-emotional development of middle school gifted students. Roeper Review, 16, 182.

Eyler, J., \& Giles, D.E. (1999). Where's the service in service-learning? San Francisco: Jossey-Bass Publishers.

Friedman-Nimz, R., O’Brien, B, Frey, B. (2005). Examining our foundations: 
Implications for gifted education research. Roeper Review, 28, 1-32.

Florida Learn \& Serve (1999). Florida learn and serve: K-12 1998-1999 Project

Descriptions. Tallahassee, Florida: Florida Learn and Serve.

Gray, M.J., Ondaatje, E.H., Fricker, R., Geshwind, S., Goldman, C.A.., Kaganoff, T., Robyn, A., Sundt, M., Vogelgesand, L., Klien, S.P., Campbell, N., \& Rosenblat, K. (1999). Combining service and learning in higher education: Evaluation of the Learn and Serve America, higher education program. Washington, D.C.: RAND.

Individuals with Disabilities Education Act, 2004.

Karnes, F.A. \& Bean, S.M. (1996). Leadership and the gifted. Focus on Exceptional Children, 29, 1-12.

Karnes, F.A. \& Riley, T.L. (2005). Competitions: what parents of gifted students should know. Understanding Our Gifted, 17(3), 8-10.

Keen, C., \& Howard, A. (2002). Experiential learning in antioch college's work-based learning program as a vehicle for social and emotional development for gifted college students. The Journal of Secondary Gifted Education, 13(3), 130-140.

Kennedy, C.H. (2004). Single-case designs for educational research. ( $1^{\text {st }}$ ed.). New Jersey: Pearson Education, Incorporated. 
Kellogg Foundation, Session II, 2005.

Kielsmeier, J.C., Scales, P.C, Roehlkepartain, E.C, \& Neal, M. (2004). Community

service and service-learning in public schools. Reclaiming Children and Youth, $13(3), 138-143$.

Lee, S-Y., Olszewski-Kubilius, P., Donahue, R., \& Weimholt, K. (2007). The effects of a service-learning program on the development of civic attitudes and behaviors among academically talented adolescents. Journal for the Education of the Gifted, 31(2), 165197.

Lee, S-Y., Olszewski-Kubilius, P., Donahur, R., \& Weimholt, K. (2008). The civic leadership institute: a service-learning program for academically gifted youth. Journal of Advanced Academics, 19(20), 272-308.

Marland, S.P., Jr. (1972). Education of the gifted, and talented. Washington. DC: U.S. Government Printing Office.

Milligan, J. (2004). Leadership skills of gifted students in a rural setting: promising programs for leadership development. Rural Special Education Quarterly, 23, $16-21$.

Miserandino, A. (1994). A practitioner's response: admitting of a future that is unlike the 
past. Roeper Review, 16, 228-229.

Moser, J. M. (2005). The power of linking service to learning. Tech Directions, 64, $18-21$

Mueller, A. (2005). Antidote to learned helplessness: empowering youth through service. Reclaiming Children and Youth, 14, 16-19.

National Association for Gifted Children (2012). The history of gifted and talented education.

The National Center for Education Statistics (1999). National student service-learning community service survey.

National and community service trust act (1990). [Legislation]. Washington, DC.

National Community Service Study (1995, July 13). Leadership.

National excellence: a case for developing america's talent, October, 1993.

National Service-Learning Clearinghouse (2012). What are the characteristics of service-learning?

No Child Left Behind Act of 2001. 20 U.S.C. 6301 et seq. (2001).

Olszewski-Kubilius, P. (2005). The center for talent development at Northwestern university: An example of replication and reformation. High Ability Studies, 16, $55-69$. 
Olszewski-Kubilius, P. \& Lee, S-Y. (2004). The role of Participation in In-School and Outsideof-School Activities in the Talent Development of Gifted Students. The Journal of Secondary Gifted Education, XV, 3, 107-123.

Ozturk, M.A., \& Debelak, C. (2008). Affective benefits from academic competitions for middle school gifted students. Gifted Child Today, 31(2), 48-53.

Park, S-K, Park, K-H, \& Choe, H-S. (2005). The relationship between thinking styles and scientific giftedness in Korea. The Journal of Secondary Gifted Education, 16, 87-97.

Perceptions: understanding and responding to what people think about service-learning (2000).

Learning in Deed, W. K. Kellogg Foundation, 1-10.

Pleasants, R., Stephens, K., Selph, H. \& Pfeiffer, S. (2004). Incorporating service learning into leadership education: duke's tips leadership institute. Gifted Child Today, 27(1), 16-21.

Renzulli, J.S. (2005). Applying gifted education pedagogy to total talent development for all students. Theory Into Practice, 44, 80-89.

Renzulli, J.S. \& Richards, S. (2000). Gifted and in the middle: Addressing the needs of gifted middle school students. Principal, 79(4), 62-63.

Renzulli, J.S., Smith, L.H., White, A.J., Callahan, C.M., Hartman, R.K., Westberg, K.L., (2002). Scales for rating the behavioral characteristics of superior students. Creative Learning Press, Incorporated. 
Rudnitski, R.A. (1994). A generation of leaders for gifted education. Roeper Review, 16, 265.

Schatz, E. (Winter 1999/2000). Mentors: Matchmaking for young people. Journal of Secondary Gifted Education, 11, 67-88.

Schollenberger, J.W. (1985). Opportunities for higher levels of thinking as they occur in service-learning. Unpublished doctoral dissertation, University of Michigan. (University Microfilms No. 8512502)

Seitsinger, A. M. (2005). Service-learning and standards-based instruction in middle schools. Journal of Educational Research, 99, 19-30.

Service-learning tip sheet (2005). National Youth Leadership Council.

Shim, J.Y., \& Kim, O.J. (2003). A study of the characteristics of the gifted in science based on implicit theory. The Korean Journal of Educational Psychology, 17, 241-255.

Skinner, R. \& Chapman, C. (1999). Service-learning and community service in k-12 public schools. Statistics in Brief.

Smith, R.M. (2009). Front and center: contradicting isolation by supporting leadership and service by students with disabilities. Teaching Exceptional ChildrenPlus, 5(5), article 4. 
Sternberg, R.J. (1990). Thinking styles: Keys to understanding student performance.

Phi Delta Kappan, 71, 366-371.

Stott, K.A. \& Jackson, A.P. (2005). Using service-learning to achieve middle school Comprehensive guidance program goals. Professional School Counseling, 9(2).

Terry, A.W. (2000). An early glimpse: service learning from an adolescent perspective. Journal of Secondary Gifted Education, 11, 1-24.

Terry, A.W., \& Bohnenberger, J.E. (1999). Connecting community problem solving to service-learning initiatives. Paper presented at the meeting of the Board of Trustees of the International Future Problem-Solving Program, Ann Arbor, MI.

Terry, A. W. \& Bohnenberger, J. E. (2003). Service learning: fostering a cycle of caring in our gifted youth. The Journal of Secondary Gifted Education, 15, 23-32.

Tillett, T. (2005). Beyond the Bench: Cultivating Environmental Leadership in the Midwest. Environmental Health Perspectives, 113, 596.

Titlebaum, P., Williamson, G., Daprano, C., Baer, J. \& Brahlen. (2002). Annotated history of service-learning: 1862-2002. National Service-Learning Clearinghouse.

Tomlinson, C.A. (2004). Sharing responsibility for differentiating instruction. Roeper Review, 26, 188-189. 
Waterman, A. (Ed.). (1997). Service-learning: Application from the research. Mahwah, NJ: Erlbaum.

Yamauchi, L.A.\& Purcell, A.K. (2009). Community involvement in a place-based program for Hawaiian high school students. Journal of Education for Students Placed at Risk, 14(2), $170-188$. 


\section{Appendix A}

Service Learning Survey

Dissertation Study

Thank you for your willingness to complete this survey.

Grade Level Age

Gender

Date

Please read the following survey items, and respond using the following scale:

5-Strongly Agree 4 -Agree 3 - Neither Agree nor Disagree 2 -Disagree

1 - Strongly Disagree

The first 10 questions refer to In-School Experiences in regard to my service learning project.

1. I am aware of needs in my community that I can do something about.

2. I believe I personally can make a difference in my community.

3. I believe students my age can influence and impact the community.

4. I know how to design and implement a service learning project.

5. I know what resources are available to help me with a service learning project.

6. I feel most adults are supportive of my efforts in service learning.

7. I am confident in expressing my opinions and ideas in front of my group.

8. I know what skills are expected of a leader in the service learning project.

9. I am committed to service learning both now and later in life.

10. I would like to continue doing service learning projects in-school.

Please provide any comments you feel are relevant to service learning as it pertains to In-School experiences: 
The second 10 questions refer to Out-of-School Experiences (on site) in regard to my service learning project.

Please read the following survey items, and respond using the following scale:

5 - Strongly Agree 4 -Agree 3 - Neither Agree nor Disagree 2 -Disagree

1 - Strongly Disagree

1. I am aware of needs in my community that I can do something about.

2. I believe I personally can make a difference in my community.

3. I believe students my age can influence and impact the community.

4. I know how to design and implement a service learning project.

5. I know what resources are available to help me with a service learning project.

6. I feel most adults are supportive of my efforts in service learning.

7. I am confident in expressing my opinions and ideas in front of my group.

8. I know what skills are expected of a leader in the service learning project.

9. I am committed to service learning both now and later in life.

10. I would like to continue doing service learning projects out-of-school.

Please provide any comments you feel are relevant to service learning as it pertains to Out-ofSchool experiences:

Thank you again for your participation!:) 


\section{Appendix B}

Service Learning Observation

Grade Level

Age

Gender

Key: Never -0

Rarely -1

Most of the time -2

Always - 3

\begin{tabular}{|l|l|}
\hline Behavior Skill & Week \\
\hline $\begin{array}{l}\text { Identifies needs } \\
\text { of community }\end{array}$ & \\
\hline $\begin{array}{l}\text { Contributes } \\
\text { ideas to service } \\
\text { learning }\end{array}$ \\
\hline $\begin{array}{l}\text { Contributes in } \\
\text { planning service } \\
\text { learning }\end{array}$ \\
\hline $\begin{array}{l}\text { Contributes to } \\
\text { the design and } \\
\text { implementation } \\
\text { of the service } \\
\text { learning project }\end{array}$ \\
\hline $\begin{array}{l}\text { Discusses and } \\
\text { applies } \\
\text { resources }\end{array}$ \\
\hline $\begin{array}{l}\text { Works with } \\
\text { other students } \\
\text { and adults } \\
\text { involved }\end{array}$ \\
\hline $\begin{array}{l}\text { Confidence in } \\
\text { expression of } \\
\text { opinion and } \\
\text { ideas in front of } \\
\text { the group }\end{array}$ \\
\hline $\begin{array}{l}\text { Demonstrates } \\
\text { leadership skills } \\
\text { involved in } \\
\text { service learning } \\
\text { project }\end{array}$ \\
\hline $\begin{array}{l}\text { Shows } \\
\text { commitment to } \\
\text { service learning } \\
\text { project }\end{array}$ \\
\hline $\begin{array}{l}\text { Shows pleasure } \\
\text { in service } \\
\text { learning }\end{array}$ \\
\hline
\end{tabular}




\section{Appendix C}

Service Learning Interview

Grade__ Age___ Gender__ Date

1. How can you make a difference in your community through service learning?

2. Has service learning improved your leadership skills? If so, how?

3. Is there another area of gifted programming or regular education that has provided you with the same leadership skills as service learning? 